\title{
Effects of Treatment on Angiogenic (Vascular Endothelial Growth Factor-2 and Matrix Metalloproteinase-2) and Antiangiogenic (Endostatin and Thrombospondin-1) Factors in Non-muscle Invasive Bladder Carcinoma
}

\author{
Kas Invaziv OImayan Mesane Kanserinde Tedavinin Anjiyogenik (Vasküler Endotelyal \\ Büyüme Faktörü-2 ve Matriks Metaloproteinaz-2) ve Antianjiyogenik (Endostatin ve \\ Trombospondin-1) Faktörler Üzerine Etkisi
}

Gökhan Temeltaş', Funda Kosova ${ }^{2}$, Oktay Üçer ${ }^{1}$, Talha Müezzinoğlu' ${ }^{1}$ Zeki Arı ${ }^{3}$

'Celal Bayar University Faculty of Medicine, Department of Urology, Manisa, Turkiye

${ }^{2}$ Celal Bayar University Faculty of Health Sciences, Department of Biochemistry, Manisa, Turkiye

${ }^{3}$ Celal Bayar University Faculty of Medicine, Department of Biochemistry, Manisa, Turkiye

What's known on the subject? and What does the study add?

The angiogenic factors in blood sample of patients with non-muscle invasive bladder carcinoma decrease after the treatment.

\begin{abstract}
Objective: We aimed to investigate possible effects of treatment on angiogenic [vascular endothelial growth factor-2 (VEGF-2) and matrix metalloproteinase-2 (MMP-2)] and antiangiogenic [endostatin (ES) and thrombospondin-1 (TSP-1)] factors in non-muscle invasive bladder carcinoma (NMIBC).

Materials and Methods: Thirty NMIBC patients and 30 age-matched controls were included in the study. For the above-mentioned markers, peripheral blood samples were drawn at three time points to be studied by enzyme-linked immunosorbent assay: before transurethral resection of bladder tumor (TURBT), at first control (20 days after the operation) and second control (at the end of intravesical immunotherapy). The mean blood levels obtained in the three measurements and those in patients and controls were compared statistically.

Results: The mean levels of VEGF- 2 and MMP- 2 in patients before TURBT were found to be statistically significantly higher than in controls $(p=0.04$ and $p=0.01$, respectively), while no significant differences were obtained between the mean ES and TSP-1 levels $(p=0.95$ and $p=0.99$, respectively). It was also found that the VEGF-2 and MMP-2 levels were significantly decreased after TURBT ( $p=0.03$ and $p=0.01$, respectively), but the tendency of these decrease was not found to be statistically significant between the first and second controls.

Conclusion: Elevated VEGF-2 and MMP-2 levels in patients with NMIBC were significantly decreased after and probably due to the TURBT, which leads to a conclusion that these angiogenic markers may be used for follow-up of NMIBC.
\end{abstract}

Keywords: Vascular endothelial growth factor-2, matrix metalloproteinase-2, endostatin, thrombospondin-1, non-muscle invasive bladder cancer

Öz

Amaç: Kas invaziv olmayan mesane kanserinde (KIOMK) tedavinin anjiyogenik [vasküler endotelyal büyüme faktörü-2 (VEGF-2) ve matriks metaloproteinaz-2 (MMP-2)] ve antianjiyogenik [endostatin (ES) and trombospondin-1 (TSP-1)] faktörler üzerine etkilerini araştırmayı amaçladık. Gereç ve Yöntem: KiOMK'li 30 hasta ve aynı yaş grubundaki 30 kontrol çalışmaya dahil edildi. Hastaların kan örnekleri üç defa alınarak yukarıda bahsedilen markerlar enzime bağlı immünosorbent testi yöntemiyle ölçüldü. İlk kan örneği transüretral rezeksiyon-mesane tümörü (TUR-MT) öncesi,

Correspondence: Oktay Üçer MD, Celal Bayar University Faculty of Medicine, Department of Urology, Manisa, Turkiye Phone: +90 5052114618 E-mail: uceroktay@yahoo.com

Received: 18.12.2016 Accepted: 07.04.2017

Presented in: $35^{\text {th }}$ Congress of the Société Internationale d'Urologie on October 15-18, 2015 in Melbourne, Australia.

Cite this article as: Temeltaş G, Kosova F, Üçer O, Müezzinoğlu T, Arı Z. Effects of Treatment on Angiogenic (Vascular Endothelial Growth Factor-2 and Matrix

Metalloproteinase-2) and Antiangiogenic (Endostatin and Thrombospondin-1) Factors in Non-muscle Invasive Bladder Carcinoma. J Urol Surg 2017;4:71-75.

oCopyright 2017 by the Association of Urological Surgery / Journal of Urological Surgery published by Galenos Publishing House. 
ikinci örnek TUR-MT sonrası 20. günde ve son örnek intravezikal immünoterapi sonrası alındı. Hasta ve kontrol grubunun marker ölçüm ortalamaları karşılaştırıldı. Ayrıca hasta grubundan alınan üç ayrı ölçüm de kendi arasında karşılaştırıldı.

Bulgular: Hasta grubunun TRU-MT öncesi ortalama VEGF-2 ve MMP-2 değerleri kontrol grubununkinden anlamlı olarak yüksel bulunurken (sırasıyla $p=0,04$ ve $p=0,01$ ), ortalama ES ve TSP-1 değerleri iki grup arasında istatistiksel olarak benzerdi (sırasıyla $p=0,95$ ve $p=0,99$ ). VEGF-2 ve MMP-2 değerlerinin hasta grubunda TUR-MT sonrası anlamlı olarak azaldığı saptanırken (sırasıyla $p=0,03$ ve $p=0,01$ ), bu azalma intravezikal tedavi sonrası devam etmekle birlikte istatistiksel olarak anlamsızdı.

Sonuç: KIOMK'li hastalardaki yüksek VEGF-2 ve MMP-2 değerleri TUR-MT sonrası muhtemel kitlenin alınmasına bağlı olarak azalmaktadır. Bu anjiyogenik markerlar KIOMK tedavi sonrası takipte kullanılabilir.

Anahtar Kelimeler: Vasküler endotelyal büyüme faktörü-2, matriks metaloproteinaz-2, endostatin, trombospondin-1, kas invaziv olmayan mesane kanseri

\section{Introduction}

With the rate of $3.2 \%$, urothelial carcinoma of the bladder (UCB) takes the ninth place among malignant tumors and twelfth among deaths caused by them (1). Non-muscle invasive bladder carcinoma (NMIBC) (pTa/pTis/pT1) incorporates $80 \%$ of UCBs, while the remaining 20\% invades the muscle [muscle-invasive bladder cancer (MIBC); (pT2 or more)] (2). Transurethral resection of bladder tumor (TURBT) is regarded as the gold standard for the treatment of NMIBC, by far. Adjuvant intravesical treatment depends on the risk groups. In intermediate-risk patients, consecutive instillations with chemotherapy or bacillus Calmette-Guérin (BCG) are required, and long-term BCG treatment is needed in high-risk patients. Despite these adjuvant treatments, NMIBC has a strong tendency to recur, and therefore long-term and frequent follow-up is inevitable (3). Some predictive markers for recurrence and/or progression in patients with NMIBC have been investigated.

Angiogenesis, defined as formation of new vasculature and, providing oxygen, nutrients and growth factors to the cancer cells, plays a crucial role in tumor growth and metastasis. It is a process regulated by angiogenic and antiangiogenic factors and these factors have been found to be associated with patients' prognosis in various cancers (4). Two major angiogenic factors are vascular endothelial growth factor (VEGF) and matrix metalloproteinases (MMPs). MMPs, which are essential for proliferation of endothelial cells, migration, and differentiation, are stimulated to be released by the most important angiogenic factor, i.e., VEGF $(4,5)$. On the other hand, two other markers dealing with this study are acting contrary. As a natural antiangiogenic factor, thrombospondin-1 (TSP-1) inhibits endothelial cell proliferation and migration and induces apoptosis (6). As for endostatin (ES), it specifically blocks angiogenesis. Blood levels of ES have been found to be elevated in some human cancers except bladder cancer (7). Similar to TSP-1, to inhibit endothelial cell migration and proliferation is the antiangiogenic mechanism of ES. It induces apoptosis not only in endothelial but also tumor cells, a property to be used as an antitumor agent inhibiting vascularity and blood supply in neoplastic tissues (8).
The goal of this study was to investigate the possible effects of treatment on the angiogenetic (VEGF-2 and MMP-2) and antiangiogenetic (ES and TSP-1) factors in NMIBC.

\section{Materials and Methods}

\section{Participants and Study Design}

Forty-one NMIBC patients who applied to the Department of Urology at Celal Bayar University Faculty of Medicine between January and September 2014, and 30 age- and sex-matched controls (group 1) comprised of patients with urolithiasis, who had no malignancies, chronic diseases and infection, were included in the prospective clinical study. TURBT operations in all the patients were performed by urologists. The exclusion criteria were as follows: pTa (in low grade) and $\geq p T 2$ UCB, another malignancy except bladder cancer and chronic diseases. Six patients with pTa and 5 patients with pT2 were excluded from the study. Only thirty patients with NMIBC, who received intravesical therapy, were enrolled in the study. Blood samples $(n=30)$ were obtained from all the patients before TURBT (group 2), twenty days after TURBT (group 3) and at the end of intravesical immunotherapy (group 4). Eighteen of 30 patients had Ta (intermediate or high risk), while the remaining 12 patients had T1 transitional cell carcinoma (TCC) of the bladder. In these 12 patients, re-TURBT was performed before intravesical immunotherapy. None of the patients received early intravesical chemotherapy. Informed consent was obtained from all the patients and controls who participated in the study and the local ethics committee approved the study protocol (approval number: 20478486-21).

\section{Enzyme-linked Immunosorbent Assay for Vascular Endothelial Growth Factor-2, Matrix Metalloproteinase-2, Endostatin and Thrombospondin-1}

The blood samples were stored at $-80{ }^{\circ} \mathrm{C}$ until the assay, but never for longer than two weeks. All of them were run in the same assay by using enzyme-linked immunosorbent assay kits (Millipore Corporation, Billerica, Massachusetts, USA) and the results were recorded in nanograms per milliliter. 


\section{Statistical Analysis}

Differences in outcome measures among the treatment groups were examined by repeated-measures ANOVA. The treatment groups and control group were compared by using the student's $t$-test and a $p$ value of less than 0.05 was considered statistically significant. Statistical analysis was done using SPSS software package (15.0; SPSS, Chicago, Illinois, USA).

\section{Results}

Both the patient and control groups were comprised of 6 females and 24 males. The mean age was found to be $67.27 \pm 8.44$ in patient group, while it was $65.74 \pm 7.22$ in control group. There were no statistically significant difference in mean age between the groups ( $p=0.54$ ). The mean levels of VEGF-2 and MMP-2 in the patients before TURBT were found to be statistically significantly higher than in the controls $(p=0.04$ and $p=0.01$, respectively), while no significant differences were obtained between the mean ES and TSP- 1 levels $(p=0.95$ and $p=0.99$, respectively). It was also found that the VEGF-2 and MMP-2 levels were significantly decreased after TURBT ( $p=0.03$ and $p=0.01$, respectively), but these tendencies of decrease were not found to be statistically significant between group 3 and 4. No significant differences between the mean levels of TSP-1 and ES before and after TURBT was found $(p=0.93$ and $p=0.93$, respectively). The mean VEGF-2, MMP-2, TSP-1 and ES levels in all the groups are summarized in Table 1 and Figure 1.

\section{Discussion}

Tumor invasion and progression in the bladder represent a multifactorial process affected by imbalance between angiogenic and antiangiogenic factors (9). VEGF and MMP are two of the most important angiogenic factors, while TSP-1 and

Table 1. The mean vascular endothelial growth factor-2, matrix metalloproteinase-2, endostatin and thrombospondin-1 levels in all the groups

\begin{tabular}{|c|c|c|c|c|}
\hline Groups & $\begin{array}{l}\text { VEGF-2 }(\mathrm{ng} / \mathrm{mL}) \\
(\text { Mean } \pm \text { SD) }\end{array}$ & $\begin{array}{l}\text { MMP-2 }(\mathrm{ng} / \mathrm{mL}) \\
(\text { Mean } \pm \text { SD) }\end{array}$ & $\begin{array}{l}\text { ES }(\mathrm{ng} / \mathrm{mL}) \\
(\text { Mean } \pm \mathrm{SD})\end{array}$ & $\begin{array}{l}\text { TSP-1 }(\mathrm{ng} / \mathrm{mL} \text { ) } \\
\text { (Mean } \pm \text { SD) }\end{array}$ \\
\hline \multicolumn{5}{|l|}{ Control $(n=30)$} \\
\hline Group $1^{*}$ & $3.28 \pm 1.85$ & $62.53 \pm 32.12$ & $43.77 \pm 20.47$ & $38.86 \pm 28.54$ \\
\hline \multicolumn{5}{|c|}{ Intervention group $(\mathrm{n}=30)$} \\
\hline Group 2** & $5.38 \pm 2.26$ & $81.54 \pm 38.13$ & $42.66 \pm 27.83$ & $38.19 \pm 27.89$ \\
\hline Group $3^{* * *}$ & $2.67 \pm 1.62$ & $62.39 \pm 18.30$ & $40.78 \pm 27.64$ & $36.26 \pm 26.29$ \\
\hline Group $4^{* * * *}$ & $2.61 \pm 2.25$ & $58.92 \pm 29.56$ & $34.92 \pm 27.30$ & $27.57 \pm 19.46$ \\
\hline \multicolumn{5}{|c|}{ Comparison of control and intervention groups ( $p$ value) } \\
\hline Group 1-Group 2 & 0.04 & 0.01 & 0.95 & 0.99 \\
\hline Group 1-Group 3 & 0.71 & 0.99 & 0.88 & 0.91 \\
\hline Group 1-Group 4 & 0.69 & 0.89 & 0.79 & 0.84 \\
\hline \multicolumn{5}{|c|}{ Comparison of intervention groups ( $p$ value) } \\
\hline Group 2-Group 3 & 0.03 & 0.01 & 0.93 & 0.93 \\
\hline Group 2-Group 4 & 0.03 & 0.01 & 0.78 & 0.85 \\
\hline Group 3-Group 4 & 0.97 & 0.87 & 0.90 & 0.86 \\
\hline \multicolumn{5}{|l|}{ *Group 1: Control } \\
\hline \multicolumn{5}{|c|}{ **Group 2: Before transurethral resection of bladder tumor } \\
\hline \multicolumn{5}{|c|}{${ }^{* *}$ Group 3: Twenty days after transurethral resection of bladder tumor } \\
\hline \multicolumn{5}{|c|}{ ****Group 4: End of intravesical immunotherapy } \\
\hline VEGF: Vascular endothe & metalloproteinase, ES: E & tatin, TSP: Thrombospc & tandard deviation & \\
\hline
\end{tabular}




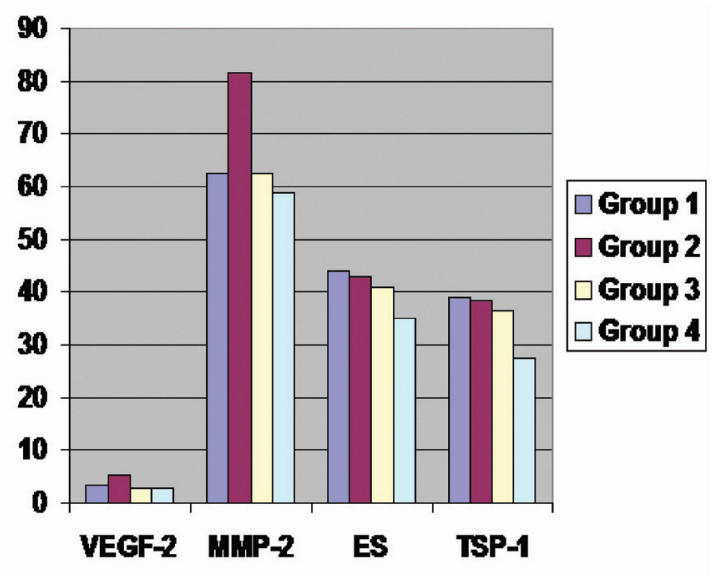

Figure 1. The graphical view of the mean vascular endothelial growth factor-2, matrix metalloproteinase-2, endostatin and thrombospondin-1 levels in all the groups

VEGF: Vascular endothelial growth factor, MMP: Matrix metalloproteinase, ES: Endostatin, TSP: Thrombospondin

ES are acting conversely. Many studies have investigated VEGF in bladder cancer. Nakanishi et al. (10) reported that muscular invasiveness of bladder carcinoma was significantly correlated with serum VEGF level, suggesting that VEGF stimulated proliferation and invasion of tumor via VEGF-2. Bernardini et al. (11) pointed out VEGF as a potential angiogenic marker for discriminating metastatic bladder cancer. Unlike these studies, we investigated serum levels of VEGF-2 in NMIBC and possible effects of TURBT and intravesical immunotherapy on VEGF-2 levels. Our study indicated that VEGF-2 levels in patients with NMIBC were higher than that in controls and this elevation significantly decreased after TURBT. This decline seemed to be continued after intravesical immunotherapy, but there were no statistically significant differences between the levels of VEGF2 before and after intravesical immunotherapy, i.e., between groups 3 and 4. Also, the VEGF-2 levels in control group were statistically similar to the levels in group 3 and group 4. All these findings may indicate that serum VEGF-2 level increases due to the mass effect of bladder tumor, then decreases after the removal of the tumor by TURBT and becomes steady after intravesical immunotherapy which prevents from progression and recurrence of bladder cancer.

As MMPs are known to be candidates for being biological markers in bladder carcinoma, some of them have been widely studied, especially the gelatinases MMP-2 and MMP-9 (12). Staack et al. (13) noticed that, compared to controls, all patient groups with bladder cancer (43 NMIBCs and 25 MIBCs) had elevated median MMP-2 concentration in blood plasma $(p<0.001)$. In their study analyzing MMP-2 in blood serum of patients with bladder carcinoma, Gohji et al. (14) found elevated concentrations in patients with advanced TCC (pT2-T4, N+, M+) in comparison to that in patients with NMIBC (Ta-T1, NO, M0). Our study enrolled only superficial bladder tumor patients. We found that serum MMP-2 levels in patients were significantly higher than in controls and significantly decreased after removal of the tumor. Like VEGF-2, this decline tended to be continued after intravesical immunotherapy, but no statistically significant differences were observed in the levels of MMP-2 between groups 3 and 4 .

Szarvas et al. (7) evaluated serum ES levels in patients with bladder cancer divided into groups according to the patients' characteristics. They found significantly higher mean ES levels in patients $(n=87)$ than in controls $(n=20)(p<0.001)$. However, they did not divide groups according to tumor stage. They also compared ES levels between patients with No/Nx $(n=71)$ and $\mathrm{N}+(\mathrm{n}=16)$ and found that the mean ES level was higher in $\mathrm{N}+$ patients than in No/Nx patients ( $p=0.006$ ). In our study, there was no significant difference in mean ES levels between controls and patients. This discrepancy between these two studies may be due to the patient selection. Although our study enrolled only NMIBC patients, their study included patients with both NMIBC and MIBC. All these findings indicate that serum ES levels elevate in invasive or advanced stage bladder cancer, but not in NMIBC. However, these results should be confirmed by further studies comparing ES levels between NMIBC and MIBC.

Donmez et al. (5) investigated TSP-1 expression in bladder cancer without including any control group. They found that TSP-1 expression in patients with invasive or advanced stage bladder carcinoma was lower than in patients with low grade or superficial cancer. In our study, TSP-1 levels in patients with NMIBC were not found to be statistically different from that in controls and it was also observed that these levels did not change significantly after NMIBC treatment.

\section{Study Limitations}

There are two important limitations of the present study. Firstly, subgroup analysis according to tumor size and grade could not be performed due to small sample size. Secondly, the progression and recurrence situations of the patients were not evaluated in the present study, thus, we did not discuss the subject with the relationship between progression or recurrence and angiogenic markers.

\section{Conclusion}

Elevated VEGF-2 and MMP-2 levels in patients with bladder carcinoma were significantly decreased after and probably due to the treatment, which leads to a conclusion that these angiogenic markers may be used in follow-up of NMIBC. 
This study analyzes serum levels of VEGF-2, MMP-2, TSP-1 and ES in NMIBC before and after TURBT and after intravesical therapy. It is confirmed that elevated plasma VEGF-2 and MMP2 levels in patients with NMIBC were significantly decreased after and probably due to the removal of the tumor, which leads to a conclusion that these angiogenic markers may be used in follow-up of NMIBC. Although this decrease seems to be continued after intravesical therapy, it was not found to be significant. Similarly, no significant results were obtained from the data about antiangiogenic markers ES and TSP-1. Further high-quality long-term studies are needed to confirm these results and to investigate the effects of treatment, progression and recurrence of bladder cancer on angiogenic and antiangiogenic markers and vice versa.

\section{Ethics}

Ethics Committee Approval: The study protocol was approved by Celal Bayar University Local Ethics Committee (Approval number: 20478486-21).

Informed Consent: Informed consent was obtained from all the patients and controls who participated in the study.

Peer-review: Externally peer-reviewed.

\section{Authorship Contributions}

Surgical and Medical Practices: G.T., O.Ü., F.K., Concept: G.T., O.Ü., Design: G.T., O.Ü., Data Collection or Processing: G.T., F.K., O.Ü., T.M., Z.A., Analysis or Interpretation: O.Ü., F.K., Literature Search: 0.Ü., Writing: 0.Ü.

Conflict of Interest: No conflict of interest was declared by the authors.

Financial Disclosure: This study was financially supported by Celal Bayar University.

\section{References}

1. Bergers $G$, Benjamin LE. Tumorigenesis and the angiogenic switch. Nat Rev Cancer 2003;3:401-410
2. Fauconnet $S$, Bernardini $S$, Lascombe I, Boiteux G, Clairotte $A$, Monnien $\mathrm{F}$, Chabannes $\mathrm{E}$, Bittard $\mathrm{H}$. Expression analysis of VEGF-A and VEGF-B: Relationship with clinicopathological parameters in bladder cancer. Oncol Rep 2009;21:1495-1504.

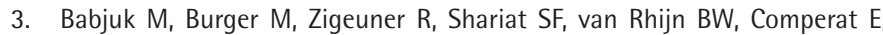
Sylvester RJ, Kaasinen E, Böhle A, Palou Redorta J, Roupret M; European Association of Urology. EAU guidelines on non-muscle-invasive urothelial carcinoma of the bladder: update, 2013. Eur Urol 2013;64:639-653.

4. Folkman J. Angiogenesis in cancer, vascular, rheumatoid and other disease. Nat Med 1995:1:27-31.

5. Donmez G, Sullu Y, Baris S, Yildiz L, Aydin O, Karagoz F, Kandemir B. Vascular endothelial growth factor (VEGF), matrix metalloproteinase-9 (MMP-9), and thrombospondin-1 (TSP-1) expression in urothelial carcinomas. Pathol Res Pract 2009;205:854-857.

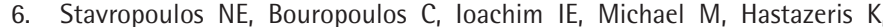
Tsimaris I, Kalogeras D, Liamis Z, Stefanaki S, Agnantis NI. Prognostic significance of angiogenesis in superficial bladder cancer. Int Urol Nephrol 2004:36:163-167.

7. Szarvas T, László V, Vom Dorp F, Reis H, Szendröi A, Romics I, Tilki D, Rübben $H$, Ergün S. Serum endostatin levels correlate with enhanced extracellular matrix degradation and poor patients' prognosis in bladder cancer. Int J Cancer 2012;130:2922-2929.

8. Schmidt A, Sommer F, Reiner M, Klotz T, Engelmann U, Addicks K, Bloch W. Differential endostatin binding to bladder, prostate and kidney tumour vessels. BJU Int 2005;95:174-179.

9. Szarvas T, Jäger T, Droste F, Becker M, Kovalszky I, Romics I, Ergün S, Rübben $\mathrm{H}$. Serum levels of angiogenic factors and their prognostic relevance in bladder cancer. Pathol Oncol Res 2009;15:193-201.

10. Nakanishi R, Oka N, Nakatsuji H, Koizumi T, Sakaki M, Takahashi M, Fukumori T, Kanayama HO. Effect of vascular endothelial growth factor and its receptor inhibitor on proliferation and invasion in bladder cancer. Urol Int 2009;83:98-106

11. Bernardini S, Fauconnet S, Chabannes E, Henry PC, Adessi G, Bittard H. Serum levels of vascular endothelial growth factor as a prognostic factor in bladder cancer. J Urol 2001:166:1275-1279.

12. Rodriguez Faba O, Palou-Redorta J, Fernández-Gomez JM, Algaba F, Eiro N, Villavicencio H, Vizoso FJ. Matrix Metalloproteinases and Bladder Cancer: What is New? ISRN Urol 2012;2012:581539.

13. Staack A, Badendieck S, Schnorr D, Loening SA, Jung K. Combined determination of plasma MMP2, MMP9, and TIMP1 improves the noninvasive detection of transitional cell carcinoma of the bladder. BMC Urol 2006;6:19

14. Gohji K, Fujimoto N, Komiyama T, Fujii A, Ohkawa J, Kamidono S, Nakajima M. Elevation of serum levels of matrix metalloproteinase-2 and -3 as new predictors of recurrence in patients with urothelial carcinoma. Cancer 1996;78:2379-2387. 